IZA DP No. 6193

Credit Constraints and Productive Entrepreneurship in Africa

Mina Baliamoune-Lutz

Zuzana Brixiová

Léonce Ndikumana

December 2011 


\title{
Credit Constraints and Productive Entrepreneurship in Africa
}

\author{
Mina Baliamoune-Lutz \\ University of North Florida \\ Zuzana Brixiová \\ UNDP Swaziland \\ and IZA \\ Léonce Ndikumana \\ University of Massachusetts
}

\section{Discussion Paper No. 6193 \\ December 2011}

\author{
IZA \\ P.O. Box 7240 \\ 53072 Bonn \\ Germany \\ Phone: +49-228-3894-0 \\ Fax: +49-228-3894-180 \\ E-mail: iza@iza.org
}

\begin{abstract}
Any opinions expressed here are those of the author(s) and not those of IZA. Research published in this series may include views on policy, but the institute itself takes no institutional policy positions.

The Institute for the Study of Labor (IZA) in Bonn is a local and virtual international research center and a place of communication between science, politics and business. IZA is an independent nonprofit organization supported by Deutsche Post Foundation. The center is associated with the University of Bonn and offers a stimulating research environment through its international network, workshops and conferences, data service, project support, research visits and doctoral program. IZA engages in (i) original and internationally competitive research in all fields of labor economics, (ii) development of policy concepts, and (iii) dissemination of research results and concepts to the interested public.
\end{abstract}

IZA Discussion Papers often represent preliminary work and are circulated to encourage discussion. Citation of such a paper should account for its provisional character. A revised version may be available directly from the author. 


\begin{abstract}

\section{Credit Constraints and Productive Entrepreneurship in Africa}

Limited access of entrepreneurs to credit constrains the creation and growth of private firms. In Africa, access to credit is particularly limited for small and medium enterprises (SMEs) due to unclear property rights and the lack of assets that can be used as collateral. This paper presents a model where firm creation and growth hinge on matching potential entrepreneurs with productive technologies, while firm growth depends on acquired capital. The shortage of collateral creates a binding credit constraint on borrowing by SMEs and hence private sector growth and employment, even though the banking sectors have ample liquidity, as is the case in many African countries. The model is tested using a sample of 20 African countries over the period 2005-09. The empirical results suggest that policies aimed at easing the binding credit constraints (e.g., the depth of credit information and the strength of legal rights pertaining to collateral and bankruptcy) would stimulate productive entrepreneurship and private sector employment in Africa.
\end{abstract}

JEL Classification: G21, L26, D24

Keywords: credit constraints, productive entrepreneurship, employment, policies

Corresponding author:

Mina Baliamoune-Lutz

University of North Florida

Coggin College of Business

4567 St. Johns Bluff Road

Jacksonville, FL 32224

USA

E-mail: mbaliamo@unf.edu

\footnotetext{
* An earlier version of this paper was presented at the African Economic Conference 2011 (October, in Addis Ababa, Ethiopia). The authors thank Jose Pineda for helpful comments. The views expressed are those of the authors and do not necessarily reflect those of their institutional affiliation.
} 


\section{Introduction}

While most African countries have recently recorded relatively high growth, even during and in the aftermath of the global financial crisis, their productivity gap with more advanced economies is still substantial. A key reason is the continued prevalence of lowproductivity activities, including a large share of subsistence agriculture. As experiences from more developed regions have shown, the transition to activities with higher value added content requires the emergence of productive entrepreneurship, nurtured not only by market dynamics but also by effective and well-targeted policies. In particular, the development of productive entrepreneurship requires a business environment that facilitates access to credit for new high-potential enterprises.

Entrepreneurs everywhere cite limited availability of finance as a major obstacle to their activities (Stein et al., 2010), but this constraint is especially binding in Africa. According to the World Bank's Enterprise Surveys, about 45 percent of firms in Sub-Saharan Africa (SSA) identify access to finance as a key obstacle to their business, relative to 13 percent in OECD countries. Access to credit and hence firm creation and growth in SSA is constrained by, among others, distortions in the financial markets, especially high collateral requirements and poorly designed and enforced property rights.

This paper utilizes a theoretical framework where firm creation and growth hinge on matching the searching entrepreneurs with production technologies and access to credit. Limited credit due to the lack of collateral slows the creation and growth of new private firms, thus hampering also job creation. The model is suitable to many African countries where financial frictions stem from the limited collateral and a weak legal framework. It generates two empirically important results. First, access to investment capital arises as a binding constraint to entrepreneurship, and this constraint prevails even in the presence of excess liquidity in the banking sector. A key constraint to access to credit is the shortage of collateralizable assets. Second, legal rights and informational depth in credit markets are shown to support firm creation and growth, and hence private sector employment.

The model is tested using data for a sample of 20 African countries over the period 200509. We use as indicator for entrepreneurship a measure of 'new business density', proxied by the new business registration per one thousand people aged 15-64 (from the World Bank's Doing Business database). The results of the empirical analysis point to possible policy interventions that may help alleviate credit constraints and encourage entrepreneurship.

The remainder of the paper proceeds as follows. After this introduction, the next section reviews the theoretical and empirical literature, with a focus on the determinants of entrepreneurship and the impact of institutional and policy reforms on entrepreneurship. The third section presents the theoretical model that underlies the empirical analysis. Section 4 contains the empirical analysis and the regression results. Section 5 summarizes the findings and discusses policy implications and possible policy interventions that may help address the constraints to entrepreneurship with a focus on the access to credit. 


\section{Overview of the literature}

\subsection{Theoretical literature}

Given the high persistence of unemployment, working poverty, underemployment and vulnerable employment in Africa, policy makers have put increasing emphasis on supporting productive entrepreneurship and small and medium enterprises (SMEs) to achieve high growth with job creation. This focus is driven by recognition that while 'necessity' (i.e., low productivity) entrepreneurship is abundant in Africa, the potential of an 'opportunity' or high productivity entrepreneurship has been mostly untapped. The unutilized potential impedes Africa's growth and employment, as the opportunity entrepreneurship is found to have a significant positive effect on development, while necessity entrepreneurship has almost none (Acs and Varga, 2005).

This paper focuses on creation and growth of productive private firms. As Baumol (1990) underscored, while the extent of entrepreneurship across societies is mostly given, policies impact whether potential entrepreneurs enter into highly productive, less productive or even destructive activities. Among other objective, such policies strive to overcome both financial and non-financial (regulatory) constraints, which have impeded productive entrepreneurship and employment across developing countries. Brixiova (2010) developed a model of non-financial constraints to firm creation in Africa's low income countries, including skill shortages of potential workers and entrepreneurs. In this paper, we focus on financial constraints to productive entrepreneurship.

In Africa, financial constraints to entrepreneurship are particularly severe because of unclear property rights and restrictions on using assets such as land as collateral. To reflect this fact, the framework presented below is a streamlined version of Brixiova and Kiyotaki (1997) who modelled how credit constraints slow down the creation and growth of private firms in transition economies in the early stages of transition, where the productive private sector was emerging and the financial sector underdeveloped. In turn, they build on research by Kiyotaki and Moore (1997) on the role of credit constraints in economies where a durable productive asset (land) acts as collateral. ${ }^{2}$

Iyigun and Rodrik (2005) developed a theoretical model where investment decisions and policy outcomes are subject to uncertainty and examine the growth effects of the interaction between institutional and policy reform and entrepreneurship. Their model showed that institutional reform has a negative growth effect in settings where entrepreneurial activity is vibrant but has a positive impact where entrepreneurial activity is weak. The authors concluded that institutional reform would be more successful where the level of entrepreneurship is weak. They then assessed the empirical relevance of their model using cross-sectional data and the ratio of self-employed to total non-agricultural employment as an indicator of entrepreneurship. They found that the relationship

\footnotetext{
2 A decrease in asset (land) prices then lowers the value of collateral and investment in the creditconstrained sector. Hart and Moore (1994) show formally how the possibility of default puts a limit on the amount of borrowing that entrepreneurs can undertake for even highly profitable projects.
} 
between institutional reform and entrepreneurship is negative and statistically significant, and interpret this result as empirical evidence in support of their theoretical proposition.

More recently, Aghion, Fally and Scarpetta (2007) examined the impact of private credit availability and stock market capitalization on firm entry and growth in advanced and emerging market economies. While their framework advances both theoretical and empirical literature, it is not directly applicable to most African countries where stock markets and more broadly non-bank financial institutions are either missing or still severely underdeveloped.

\subsection{Empirical literature}

The empirical literature relevant to the issues we examine in this paper relates to two areas: (i) the empirical research on the determinants of entrepreneurship - in particular the role of credit and liquidity - and (ii) empirical studies on policy and institutional reforms and their impact on entrepreneurship. ${ }^{3}$

The role of information sharing and lender and borrower legal rights for access to credit is key for this study. Some studies have found that information sharing facilitates access to credit (Jappelli and Pagano, 2002; Djankov et al., 2007; Brown et al., 2009). ${ }^{4}$ However, Negrin (2001) shows that wider information sharing led to less access to bank credit for small and medium-sized firms in Mexico. Regarding whether better legal rights ease access to credit, Demirgüç-Kunt and Maksimovic (1998) find that the proportion of firms using long-term external financing is larger in countries with efficient legal systems. Since long-term external finance is often necessary for long-term investment, credit constraints for entrepreneurs planning to undertake long-term projects may be greater in countries with inefficient legal systems. ${ }^{5}$

Qian and Strahan (2007) show that the effects of creditor rights on loans depend on borrowers' characteristics such as the size and tangibility of their assets. Specifically, foreign banks "appear especially sensitive to the legal and institutional environment, with their ownership declining relative to domestic banks as creditor protection falls" ( $\mathrm{p}$. 2803). This result is particularly relevant to African countries that rely highly on the presence of foreign banks. Using data from 12 transition countries, Haselmann et al. (2010) find that the supply of bank credit increased after a legal change and that changes in collateral law matter more than changes in bankruptcy law for increased bank lending. The second line of empirical research focuses on the effects of policy and institutional reforms on the creation and growth of entrepreneurial activity. However, most of the

\footnotetext{
${ }^{3}$ For a recent review of literature on the links between entrepreneurship, reforms, and development (growth), see Baliamoune-Lutz (2010). More broadly, for studies on links between financial development and growth see, for example, King and Levine 1993, Rajan and Zingales, 1998; Baliamoune-Lutz and Ndikumana, 2007; Beck and Demirgüç-Kunt, 2008; and Baliamoune-Lutz, 2011.

${ }^{4}$ See also the survey by Japppelli and Pagano (2000).

${ }^{5}$ Using data from 49 countries and controlling for legal origin, La Porta et al. (1998) report "that commonlaw countries generally have the strongest, and French civil-law countries the weakest, legal protections of investors, with German- and Scandinavian-civil-law countries located in the middle."
} 
studies have examined the effects of tax system reforms, and focused primarily on OECD countries and in many cases using micro-level (firm-level or individual) data. However, a limited number of studies have focused on other reforms besides taxation. Using establishment-level data from the manufacturing sector, Gaston and Werner (2002) explore the effects of financial liberalization on fixed investment in Mexico, focusing on the role of real estate as collateral. They find that financial constraints were reduced for the smallest firms, but not for larger ones, and given that banks relied on collateral in their lending decision, the importance of having real estate rose.

Baliamoune-Lutz (2007) empirically tests the Iyigun-Rodrik (2005) model using data from developed and developing countries and exploring the role of institutional and policy reforms on contributions of entrepreneurship to development. She also finds that the effect of policy reforms (trade reforms, proxied by openness to trade) is negative when entrepreneurial activity is weak and positive when it is vibrant, while the effects of institutional reforms (measured by the International Country Risk Guide composite index) is positive when the level of entrepreneurship is low and negative when it is high.

Finally, Baliamoune-Lutz (2010) focuses only on developing countries and uses panel data for the period 1990-2002 and Arellano -Bond GMM estimations to explore the impact of institutional and policy reforms on the growth effects of entrepreneurship. She obtains empirical evidence suggesting that the interplay of trade reforms and entrepreneurship has a negative impact on growth, whereas the interplay of financial sector reform and entrepreneurship has a non-linear positive effect on growth. ${ }^{6}$ The joint effect of institutional reforms and entrepreneurship on growth is not significant though.

\section{A model of entrepreneurship}

This section presents a model where entrepreneurship, specifically firm creation and growth, is constrained due to the lack of access to finance, which in turn is limited by the lack of collateral. The model is a streamlined version of the model in Brixiova and Kiyotaki (1997), which was developed for transition economies at the early stages of transition, with emerging private sectors. In this paper we apply it to African countries, where in many instances formal and productive private sector is still underdeveloped.

As the World Bank Enterprise Surveys document, one of the key constraints faced by firms in Africa is the lack of access to credit (Appendix A, Figure A1). By emphasizing the lack of collateral and the weak application of the rule of law, the framework below is particularly suitable for most African countries where the financial sectors are dominated by banks and binding credit constraints co-exist with excess liquidity. Specifically, the weak implementation of the legal framework makes banks require high collateral (in some cases over 100 percent of the loan), leaving the financial needs of many potential entrepreneurs unaddressed. We provide the details of the analytical framework below.

\footnotetext{
6 This seems to be consistent with Claessens and Perotti (2007: 748) who conclude that financial liberalization with the view to increase access "may in practice increase fragility and inequality, and lead to political backlash against reforms," in the absence of strong oversight institutions.
} 
The population is normalized to one and consists of infinitely-lived entrepreneurs dynasties $^{7}-$ and workers, with population shares $\mu$ and $1-\mu$, respectively. All agents are endowed with one unit of time every period and have risk neutral preferences in consumption of a single good, $c$. When starting their search, entrepreneurs are endowed with net worth $a_{0}>0$. The entrepreneur searches for a business opportunity; the search costs her $d(x)=x^{2} / 2 \gamma$ units of the consumption good per unit of time; $\gamma>0$ is the parameter of search efficiency. In turn, she finds the opportunity according to a Poisson process with the arrival rate of $x$. She produces output $(y)$ in the formal sector with labor $(n)$, productivity $(z)$ and capital $(k)$ according to the production function:

$$
y=\frac{1}{1-\alpha}(z k)^{\alpha} n^{1-\alpha}
$$

The output can be used either for investment or consumption. Capital is entrepreneurspecific, implying that once the entrepreneur invests in it, she is the only one who can use the accumulated stock until she retires and passes it on to her successor. Due to imperfections in legal frameworks and property rights in Africa, the outside value of the accumulated capital is lower than its worth to the entrepreneur, and in some cases significantly so. Put differently, in the case of default, lenders can recover only $(1-\theta)$ portion of the accumulated capital, where $\theta$ reflects the weaknesses in the legal framework. The lenders limit the loan to the entrepreneur, $b$, to the recoverable value of her capital, that is: ${ }^{8}$

$$
b \leq(1-\theta) k
$$

The entrepreneur finances capital $(k)$ from both borrowing $(b)$ and her own net worth $(a)$, which she accumulates according to:

$$
\dot{a}=y n-w n-r b-c
$$

where $w$ is the wage rate and $r$ is the real interest rate on debt, which in equilibrium equals the rate of time preference (and time $t$ is suppressed.

Private firms are destroyed at exogenously given rate $\delta>r$. The exiting entrepreneur consumes all her accumulated net worth except $a_{0}$ which she passes on her successor, derives utility $a-a_{0}$, and dies immediately after. The successor searches for another business opportunity, with the initial net worth $a_{0}$. In addition to the formal sector,

\footnotetext{
${ }^{7}$ That is when the entrepreneur retires, she passes accumulated capital on to her successor.

${ }^{8}$ The value of $\theta$ depends on the specificity of the capital and strength of the legal framework, including the bankruptcy law. Renting the capital is not an option as the rental market is mostly absent in Africa.
} 
output can be produced in the informal sector according to $Y_{u}=1 /(1-\alpha) Z_{u}^{\alpha} N_{u}^{1-\alpha}$, where $Z_{u}$ is productivity and $N_{u}$ is the informal sector employment. Denoting $m_{p}$ to be the share of entrepreneurs operating private firms and $n$ the number of workers per firm, the following labor market equilibrium condition for workers needs to hold:

$$
1-\mu=N_{u}+m_{p} n
$$

Letting $m_{u}$ be the share of entrepreneurs searching for business opportunities and $m_{p}$ the share of entrepreneurs running firms, the equilibrium conditions for entrepreneurs satisfy:

$$
\mu=m_{u}+m_{p}
$$

The change in the number of entrepreneurs searching for business opportunities, $\dot{m}_{u}$, is given by the difference between inflows into the pool of searching entrepreneurs, $\delta\left(\mu-m_{u}\right)=\delta m_{p}$ and the exits from it, $x m_{u}$. From (5), $\dot{m}_{p}=-\dot{m}_{u}$, with the initial value of number of private firms, $m_{p 0}$, set to 0 .

$$
\dot{m}_{u}=\delta m_{p}-x m_{u}=\delta\left(\mu-m_{u}\right)-x m_{u}
$$

Taking wages and interest rates as given, the equilibrium is characterized by (i) entrepreneur's choice of search effort, labor, capital, debt, and savings that maximize the expected discounted utility; (ii) worker's choice of allocation of labor and consumption; (iii) products and debt markets that clear and (iv) labor markets that satisfy (4)-(6).

The equilibrium wage rate rises in the aggregate capital stock $(K)$, and is determined as follows:

$$
w=\frac{z K}{1-\mu} \equiv w(K)
$$

where $K=\int_{0}^{\mu} k_{i} d i$, with $k_{i}$ being capital of an entrepreneur $i$. 
With the constant return-to-scale production function and output price normalized to 1 , profits are zero in equilibrium, that is $1 /(1-\alpha)(z k)^{\alpha} n^{1-\alpha}=w(K) n+R(K) k$ and the return on capital, $R(K)$ becomes: ${ }^{9}$

$$
R(K)=\frac{\alpha}{1-\alpha} z w(K)^{-(1-\alpha) / \alpha}
$$

When $K<\bar{K}$, the rate of return on capital is above the real interest rate on debt, $R(K)>r$ and the entrepreneur borrows up to the credit limit for capital investment, i.e. the credit constraint is binding and $b=(1-\theta) k$. The entire net worth is spent on the down-payment for capital: $a=k \theta$. The return on net worth exceeds the real interest $(r)$ by the leverage $(1 / \theta)$ times the difference between the return on capital that the entrepreneur owns and interest rate she pays for borrowing.

Suppressing the time subscripts and denoting $J^{u}$ and $J(a)$ as a present discounted value of an entrepreneur searching for a business opportunity and an entrepreneur running a private firm with net worth $a$, respectively, the corresponding Bellman equations are:

$$
\begin{gathered}
r J^{u}=\max _{x}\left\{\frac{-x^{2}}{2 \gamma}+x\left[J\left(a_{0}\right)-J^{u}\right]\right\} \\
r J(a)=\delta\left[a-a_{0}+\left(J^{u}-J(a)\right)\right]+\frac{\partial J}{\partial a} \dot{a}
\end{gathered}
$$

where (9) states that the return from searching for a business opportunity equals the net expected return from running a business with the net worth $a_{0}$. According to (10), the return on running a firm consists of gains from accumulating net worth and expected utility of consumption at the time of exiting from the labor force and net expected gain from search. ${ }^{10}$

To solve for the steady state equilibrium, equation (10) can be re-written as follows, given the linearity of the utility function and the accumulation rule (3):

\footnotetext{
${ }^{9}$ From profit maximizing condition for capital, $R(K)=\frac{\alpha}{1-\alpha} z^{\alpha} k^{\alpha-1} n^{1-\alpha}$. Substituting the profit maximizing condition for labor, that is $w(K)=(z k)^{\alpha} n^{-\alpha}$ yields (8).

10 The expected utility of consumption, $\frac{\partial J}{\partial a} \dot{a}$, consists of the marginal value of net worth of an entrepreneur running a business and the change in net worth over time.
} 


$$
\begin{aligned}
& J(a)=J\left(a_{0}\right)+\beta\left(a-a_{0}\right) \\
& r J\left(a_{0}\right)=\beta \dot{a}_{0}+\delta\left(J^{u}-J\left(a_{0}\right)\right) \\
& \dot{\beta}=\left(\delta-\frac{R(K)-r}{\theta}\right) \beta-\delta
\end{aligned}
$$

where $\beta$ denotes the marginal value of net worth of an entrepreneur running a business $(\partial J / \partial a)$. Defining the shadow value of the business opportunity as $\lambda=J\left(a_{0}\right)-J^{u}$, i.e., the difference between the present discounted value of an entrepreneur running a firm with a net worth $a_{0}$ and the entrepreneur searching for a business opportunity, marginal cost of search equals marginal benefit: $x / \gamma=\lambda$ and:

$$
\begin{array}{r}
\dot{\lambda}=\gamma \lambda^{2} / 2+(r+\delta) \lambda-\beta a_{0} \\
\dot{m}_{p}=\gamma \lambda\left(\mu-m_{p}\right)-\delta m_{p} \\
\dot{K} \leq\left(r+\frac{R(K)-r}{\theta}\right) K+\dot{m}_{p} \frac{a_{0}}{\theta}-\delta K
\end{array}
$$

The steady state equilibrium is described by (13) - (16), where $\dot{\beta}=\dot{\lambda}=\dot{m}_{p}=\dot{K}=0$. Moreover, the binding credit constraint implies that in equilibrium the number of entrepreneurs running private firms is limited (i.e., lower than in a situation without a binding credit constraint): $\frac{\delta \gamma \hat{\lambda} \mu}{\delta+\bar{\lambda}} k_{0}<(\delta-r) \bar{K} \Leftrightarrow R\left(K^{*}\right)>r$, where $\bar{K}$ solves $R(K)=r$ and $\hat{\lambda}$ solves $\gamma \lambda^{2} / 2+(r+\delta) \lambda=r k_{0}$. This credit constraint, which is binding even in the presence of adequate liquidity, $\bar{K}$, stems from the lack of collateral/net worth $a_{0}$, or put differently, from high $\theta$ (the share of entrepreneurs' capital that cannot be pledged as collateral).

The above model has at least two important empirical implications. First, the model suggests a positive relationship between firm creation and growth on one hand and measures of access to credit, notably banking sector development, liquidity, and informational depth of credit markets on the other. Secondly, the model points to a positive relationship between firm creation and growth and lender and borrower legal rights. Clearer and better enforced lender and borrower legal rights as well as easier availability of information on credit markets lead also to increased employment in the productive private sector. 


\section{Empirical analysis}

\subsection{Data and methodology}

We test the empirical relevance of our model for Africa in two ways. First, we examine graphically the association between variables of interest, which we define below. Second, we estimate, using regression models, the relationship between firm startups, indicators of financial development and liquidity in the banking sector, and indicators of the quality of laws and information governing collateral assets. The estimation equation is specified as follows:

$E N T_{i, t}=\alpha_{0}+\alpha_{1} L A W_{i, t}+\alpha_{2} C R E D I T_{i, t}+\alpha_{3} L I Q_{i, t}+\beta^{\prime} Z+\varepsilon_{i, t}$

Where ENT (entrepreneurship), is proxied by 'new business density', which is measured by new business registrations per 1,000 people aged 15-64 from Doing Business database (World Bank database on line). New businesses registered are the number of new limited liability corporations registered in the calendar year.

The right-hand side of equation (17) includes three main indicators of access to credit and collateral. The first is the strength of legal rights index $(L A W)$, which "measures the degree to which collateral and bankruptcy laws protect the rights of borrowers and lenders and thus facilitate lending" (World Bank Doing Business database online). This index is measured on a 0 -to-10 scale, with higher scores indicating that collateral and bankruptcy laws are better designed to expand access to credit. The second variable is the depth of credit information index (CREDIT), which "measures rules and practices affecting the coverage, scope and accessibility of credit information available through either a public credit registry or a private credit bureau" (World Bank Doing Business database online). This index is measured on a 0-to-6 scale, with higher scores indicating stronger depth of credit information. The third indicator is the ratio of bank liquid reserves to bank assets $(L I Q) .{ }^{11}$ The $\mathrm{Z}$ vector includes additional control variables. These are domestic credit to the private sector (\% of GDP), per-capita income (in log) and, in some estimations, 'public credit registry coverage (\% of adults)' and broad money. In the robustness checks, we also control for the cost of business start-up procedures (\% of GNI per capita), and for human capital (the results associated with human capital are omitted due to consistent lack of statistical significance).

All variables are from the World Bank databases online (World Development Indicators and Doing Business). For the countries in our sample, data on the dependent variable are available only for the period 2004-2009, while data on the strength of legal rights and depth of credit information are available only since 2005. We can thus only include data for the period 2005-2009. We have an unbalanced panel and the sample includes 20

\footnotetext{
${ }^{11}$ An important constraint to credit supply in most African banking sectors is the shortage of long-term loanable funds. Unfortunately it is difficult to get good data on this and our model does not include it, but it is important to acknowledge this issue for further research.
} 
countries. The sample is reduced to 11 countries when we control for the effects of bank liquid reserves due to lack of data on this variable in the other nine countries.

The empirical analysis is implemented using pooled-panel and random-effects generalized least squares (GLS) estimations. Table 1 shows correlations among relevant variables. The estimation results are presented in Tables 2 and 3.

\subsection{Graphical examination ${ }^{12}$}

Figure 1 portrays the fitted relationship between new business density and the strength of legal rights. Our theoretical model suggests that we should find a positive relationship between the two. Figure 1, however, shows that the relationship has an inverted-U form; it is initially positive then turns negative after the index reaches a value of about 6 . Given that in our sample most countries (14 out of 20 countries in the large sample), have values of the legal rights index less than 6 , this suggests that strengthening legal rights in credit markets would have a positive impact. ${ }^{13}$ Figure 2 shows the association between the depth of credit information and new business density. Again, the relationship seems to be nonlinear and the graph suggests diminishing returns to improvements in the depth of credit information, although the correlation appears weak.

In addition, we use data from the World Bank's Enterprise database on a large group of African countries (not all in our sample) ${ }^{14}$ on loans requiring collateral, value of collateral needed for a loan, and the percentage of firms identifying access to finance as a major constraint.

In Figures 3 and 4, we show the association (fitted values) of new business density with loans requiring collateral (percent of the loan amount) and the value of collateral needed for a loan (percent of the loan amount), respectively. There is a clear negative association of new business density with the percentage of loans requiring collateral and with the value of the collateral. This seems to be confirmed by the relationship portrayed in Figure 5. There is a positive association between 'access to finance being a major constraint' and the value of collateral need for a loan.

\subsection{Estimation results}

Table 1 presents the coefficients of correlation among relevant variables. The correlations of new business density with the ratio of self-employed (in total employed), the cost of business startup, and bank liquid reserves-to-bank assets ratio are negative and statistically significant. The correlation of new business density with income, the ratio of broad money, and the ratio of credit to the private sector is positive and statistically

\footnotetext{
${ }^{12}$ See also the graphs in Appendix A

${ }^{13}$ This observation can be in part explained by excessive resort to legal systems in countries with stronger legal rights for lenders and borrowers, with entrepreneurs and lenders spending time in court rather than searching for profitable business opportunities.

${ }^{14}$ We could not use data from this database for our estimations since the countries in our sample did not have values for these variables which would have severely limited the number of observations.
} 
significant. On the other hand, there is no significant correlation between new business density and the strength of legal rights or the depth of credit information. In all the cases where the coefficients are statistically significant, the coefficients related to correlations of self-employed with the other variables have opposite signs relative to the coefficients related to correlation between new business density and the other variables. This seems to suggest that self-employment and new business density behave in completely different ways and could be affected by different factors. The two main indicators of the quality of credit markets (strength of legal rights and the depth of credit information) do not have significant positive correlation with new business density or the ratio of self-employed.

Table 2 reports the results from OLS estimations on pooled-panel data. We note that income and the strength of legal rights have positive and statistically significant coefficients and these results are robust. On the other hand, the coefficient on the variable 'depth of credit information' is negative and statistically significant in three estimations (columns 2-4) and positive but nonsignificant in three other estimations (columns 5-7). Interestingly, the indicators of liquidity and financial market development either have a negative coefficient (bank liquid reserves to bank assets ratio in columns 3-5), or are statistically nonsignificant (broad money and credit to the private sector in columns 6 and 7 , respectively). In columns 5-7, we investigate the presence of non-linearity of the relationship between new business density and the strength of legal rights and the depth of credit information. The results indicate the relationship between new business density and the strength of legal rights has an inverted-U shape.

Next, we perform random effects GLS estimations and report the results in Table $3 .^{15}$ Again, the results show that there is strong evidence that new business density is positively associated with per-capita income. On the other hand, the relationship of new business density with the strength of legal rights and the depth of credit information has an inverted-U shape. This seems to suggest that returns or gains from reforms are high at low levels of "quality"/development of institutions, and lower at higher levels of institutional sophistication/development. It supports investments in reforms for less developed countries where institutions are disproportionately weak.

As an additional robustness check, we also control for the cost of business startup. However, this variable turns out to be statistically nonsignificant. As noted earlier, in other estimations (not shown but results may be requested from the authors), we control for the role of primary and secondary school enrolments (proxies for human capital), but these variables were statistically nonsignificant.

The results in Table 3 show that the turning point for the strength of legal rights occurs where the index values between 6.0-6.9, whereas the turning point for the depth of credit information is for a value of about 2.75. In our sample, only three countries, Kenya, South Africa, and Tunisia, had values for the depth of credit information higher than 3. Four countries - Kenya, Nigeria, South Africa and Zambia - have values for the index of the strength of legal rights greater than 7 . Thus, the majority (at least $75 \%$ ) of the

${ }^{15}$ In contrast to the OLS method, the GLS estimation technique eliminates the correlation over time. 
countries are at or below the turning point and should still see a positive link between entrepreneurship (measured by new business density) and improvements in the strength of legal rights and the depth of credit information. Put differently, entrepreneurs in African countries where a binding credit constraint exists in spite of excess bank liquidity and where the quality of the strength of legal rights (protection of lender and borrower rights) and the depth of credit information is poor, would benefit significantly from improvements in legal rights and the depth of credit information.

\section{Summary and policy implications}

In this paper, we proposed a theoretical model that is applicable to African credit markets where entrepreneurship, or specifically the creation and growth of private firms, hinge on matching potential entrepreneurs with productive technologies and on access to capital. The implications of the model are tested empirically using a sample of 20 African countries over the period 2005-09. Two estimation techniques are used: the pooled-panel data regressions and random-effects GLS estimations. We use new business registrations per one thousand people aged 15-64 as proxy for entrepreneurship.

A first result of the empirical analysis is that the quality of legal rights has a positive impact on 'new business' density, our proxy for entrepreneurship. More interestingly, the relationship is shown to be non-linear, depicting an inverted-U shape. The estimated coefficients suggest a turning point of the index of the quality of legal rights in the range of 6-6.9 (on a range of 0-10). Only four countries in the sample have an index above 7. This suggests that the majority of African countries would benefit from policies leading to improvements in the quality of legal rights as this will promote entrepreneurship.

Secondly, we find an inverted-U shaped relationship between new business density and the depth of credit information. The turning point of the index of the depth of credit market information is about 2.75. Only three countries have an index above 3 . This again suggests that African countries can gain substantially from policy interventions aimed at developing information on borrowers and creditors, as this would facilitate identification of profitable activities and increase access to credit for new entrepreneurs.

The results in this study provide pertinent policy insights for the agenda of promoting productive entrepreneurship in Africa. This naturally is no easy task. Yet, it must be a central component of a national strategy for achieving growth that is strong, sustained and shared. ${ }^{16}$ This in turn is a key prerequisite for prosperity on the continent in terms of economic wellbeing as well as social and political stability.

Indeed as the recent developments in North Africa ${ }^{17}$ and the unfolding events in other parts of the continent demonstrate, the failure to build a national economy that provides opportunities for social and economic upward mobility for the majority of the population has dire consequences on national political stability. Given the very high rates of youth

\footnotetext{
${ }^{16}$ For a discussion of the prerequisites for strong, sustained, and shared growth in Africa, see, among others: Kasekende, Brixiova, and Ndikumana (2010); AfDB, UNECA, and AU (2010).

${ }^{17}$ See AfDB (2011) for an analysis of the factors that led to the political crisis in Tunisia.
} 
unemployment across Africa, it is likely that regimes will continue to face strong pressure from the tide of the youth that feels disenfranchised due to lack of employment opportunities. However, African government sectors are not able to absorb the growing labor supply on the continent. Besides attracting FDI, the attention then must turn to strategies for supporting productive entrepreneurship as a way of building a national economy that is sustainable and able to compete regionally and globally.

Supporting productive entrepreneurship requires a wide range of policy interventions aimed at alleviating underlying economy-specific constraints. The evidence in this paper points to two key areas of policy interventions that have potentially high impact on entrepreneurship, namely: promoting access to credit, and improving the business environment especially in the area of design and enforcement of legal rights.

This study particularly stresses the problem of access to credit arising from the inability of potential entrepreneurs to meet the collateral requirements imposed by financial institutions. In the case of African banking systems, the problem is not so much that of lack of resources per se, but rather weak legal systems that do not enable lenders to recover fully the pledged collateral. As result, excess liquidity in the banking sectors coexists with credit constraints. This suggests that in addition to interventions aimed at containing the cost of credit, policy interventions must also focus on strengthening legal systems alongside alleviating the quantitative barriers to access to credit.

The setting up and strengthening of credit bureaus and associated institutions that collect information on creditors and borrowers constitutes a key element of strategy to promote productive entrepreneurship. The gains arise both through the reduction of perceived credit risk as well as through the provision of market signals on the profitability of various investment activities in the economy. New and innovative methods such psychometric testing of loan applicants on their willingness to repay loans applied by, for example, Standard Bank in some East and Southern Africa countries can also help ease credit constraints. These initiatives in turn encourage entrepreneurship and enhance efficiency in the allocation of investment capital across activities. The potentially high social returns to investments in setting up these institutions and methods justify the scaling up of budgetary and aid allocations to support such policy initiatives as part of the broader agenda for promoting private sector development in the continent.

Despite some progress made in liberalizing financial systems in Africa, there is still a long way to go to achieve efficiency in the sector. A key constraint is the lack of competition in the banking sector, which in turn manifests itself in excessive collateral requirements. While government direct control and ownership of financial institutions have declined substantially, indirect control on credit allocation is still prevalent. This control results in allocational inefficiencies of loanable funds: bank credit is allocated to politically connected individuals and bank insiders at relatively low interest rates, some of which finances unproductive activities. ${ }^{18}$ At the same time, the SMEs are 'priced out'

\footnotetext{
${ }^{18}$ In a detailed case study on the financial sector in Burundi, Nkurunziza, Ndikumana and Nyamoya (2011) provide evidence on inefficiencies in the allocation of resources that are driven by political interference in the management of the financial institutions.
} 
of the market due to high cost of borrowing (collateral). Increasing competition and reducing political influence on the functioning of financial institutions are key prerequisites to promoting access to credit as a means of supporting entrepreneurship.

This paper thus suggests that emphasis should be on three interventions: (1) design and enforcement of legal rights especially targeting collateralizable assets; (2) fostering competition in the banking sector, especially in terms of access to credit; (3) developing and strengthening institutions and mechanisms for access to creditor and borrower information. It is particularly important to design and enforce property rights that enable entrepreneurs to utilize their durable assets, such as land, to secure bank loans. In most African countries, this is not possible as households do not have formal titles to their land, and the constraint is often particularly severe for women-headed households.

Taking a broader view, as new entrepreneurs are viewed as risky by banks, they are less likely to secure the needed capital to start businesses. It is not in the banks' best interest to lend to such borrowers given the high risk and also because they have alternative, less risky activities to lend to. Given the high social returns to supporting entrepreneurship though, the costs associated with the risk inherent to lending to new productive activities should be spread across the society. This could be done through the design of loan guarantee schemes or grants, with explicit and detailed provisions to ensure that the funds covered by the schemes are directly financing new activities. This may require, among others, tracking mechanisms to minimize the risk of diversion of the resources into speculative activities. We leave this important topic for further research. 


\section{References}

Acs, Z. J. and Varga, A. (2005). "Entrepreneurship, Agglomeration and Technological Change." Small Business Economics, 24 (3): 323-334.

AfDB (2011). "The Revolution in Tunisia: Economic challenges and prospects." Economic Brief, March 11. http://www.afdb.org/en/news-and-events/article/tunisianrevolution-afdb-brief-on-economic-outlook-7904/

AfDB, UNECA, and African Union (2010). "Achieving strong, sustained and shared growth in Africa in the post-crisis global economy." Prepared for and presented at the 2010 KOAFEC Ministerial Conference, Seoul, Korea, September 14-17 2010. http://www.afdb.org/en/knowledge/publications/policy-briefs/

Aghion, P., T. Fally and S. Scarpetta (2007). "Credit constraints as a barrier to the entry and post-entry growth of firms.” IZA Discussion Paper No. 3237, December 2007

Baliamoune-Lutz, M. (2011). "Financial development and income in African countries." Forthcoming, Contemporary Economic Policy.

Baliamoune-Lutz. M. (2010). "Policy reform and entrepreneurship in developing countries." Chapter 9 in Naudé, W.A., ed., Entrepreneurship in Economic Development. Palgrave Macmillan.

Baliamoune-Lutz, M. (2007). "Entrepreneurship, reforms, and development: Empirical evidence." Working Paper No. 38/2007, International Centre for Economic Research (ICER), Italy.

Baliamoune-Lutz, M., and L. Ndikumana (2007). "The Growth effects of openness to trade and the role of institutions: New evidence from African countries." Policy Paper 6. Boston: Institute for Economic Development, Department of Economics, Boston: Boston University.

Baumol, W. J. (1990). "Entrepreneurship: Productive, unproductive and destructive." Journal of Political Economy, 98 (5): 893-921.

Beck, T. and A. Demirgüç-Kunt (2008). "Access to finance: An unfinished agenda." The World Bank Economic Review, 22(3): 383-396.

Brixiova, Z. (2010). "Unlocking productive entrepreneurship in Africa's least developed countries." African Development Review, 22 (3):440-451.

Brixiova, Z. and N. Kiyotaki (1997). "Private sector development in transition economies." Carnegie-Rochester Conference Proceedings on Public Policy, 46(1), 241279. 
Brown, M, T Jappelli, and M Pagano (2009). "Information sharing and credit Market performance: Firm-level evidence from transition countries." Journal of Financial Intermediation 18: 151-172.

Claessens, S. and E. Perotti (2007). "Finance and inequality: Channels and evidence." Journal of Comparative Economics, 35(4):748-773.

Cullen, J. and R. Gordon (2007). "Taxes and entrepreneurial risk-taking: Theory and evidence for the US.” Journal of Public Economics, 91: 1479-1505.

Demirgüç-Kunt, A. and V. Maksimovic (1998). "Law, finance and firm growth." Journal of Finance, 53(6): 2107-37, 1998.

Dercon, S. and L. Christiaensen (2010). "Consumption risk, technology adoption and poverty traps: Evidence from Ethiopia." Journal of Development Economics, forthcoming.

Djankov, S., C. McLiesh and A. Shleifer (2007). "Private credit in 129 countries ." Journal of Financial Economics, 2(84): 299-329.

Hart, O. and J. Moore (1994). "A Theory of debt based on the inalienability of human capital." Quarterly Journal of Economics, 109: 841-79.

Haselmann, R., K. Pistor and V. Vig (2010). "How law affects lending." Review of Financial Studies 23(2): 549-580.

Iyigun, M. and Rodrik, D. (2005). "On the efficacy of reforms: Policy tinkering, institutional change, and entrepreneurship." In Institutions and Growth, T. Eicher and C. G. Penalosa, eds., MIT Press.

Jappelli, T and M Pagano (2002). "Information sharing, lending and defaults: Crosscountry evidence." Journal of Banking and Finance, 26: 2017-2045.

Jappelli, T and M Pagano (2000). "Information sharing in credit markets: A survey". CSEF Working Paper 36.

Kasekende, L.; Brixiova, Z. and Ndikumana, L. (2010). “Africa: Africa's countercyclical response to the crisis." Journal of Globalization and Development, Vol. 1 (1), Art. 16.

King, R. and R. Levine (1993). "Finance and growth: Schumpeter might be right." Quarterly Journal of Economics, 108 (3): 717-37.

Kiyotaki, N. and J. Moore (1997). "Credit cycles." Journal of Political Economy, 105: 211-248. 
La Porta, R, F. Lopez-de-Silanes, A. Shleifer, and R. Vishny (1998). "Law and finance." Journal of Political Economy, 106 (6): 1113-55.

Nkurunziza, J.D., L. Ndikumana, and P. Nyamoya (2011). "The Financial system in Burundi: An investigation of its efficiency in resource mobilization and allocation." Forthcoming, NBER Working Paper. Prepared for the NBER African Success Stories Project (http://www.nber.org/AfricanSuccesses/projects.html).

Negrin, J. L. (2001). "Credit information sharing mechanisms in Mexico: Evaluation, perspectives, and effects on firms' access to bank credit." Center for Research on Economic Development and Policy Reform, Working Paper No. 114.

Qian, J. and P. E. Strahan (2007). "How laws and institutions shape financial contracts: The case of bank loans." Journal of Finance, 62 (6): 2803-2834.

Rajan, R. and L. Zingales (1998). "Financial dependence and growth." American Economic Review, 88 (3): 559-86.

Stein, P., T. Goland and R. Schiff (2010). Two Trillion and Still Counting: Assessing the Credit Gap for Micro, Small and Medium-Size Enterprises in the Developing World, McKinsey\&Company and IFC: Washington, DC. 
Figure 1. Strength of legal rights and entrepreneurship

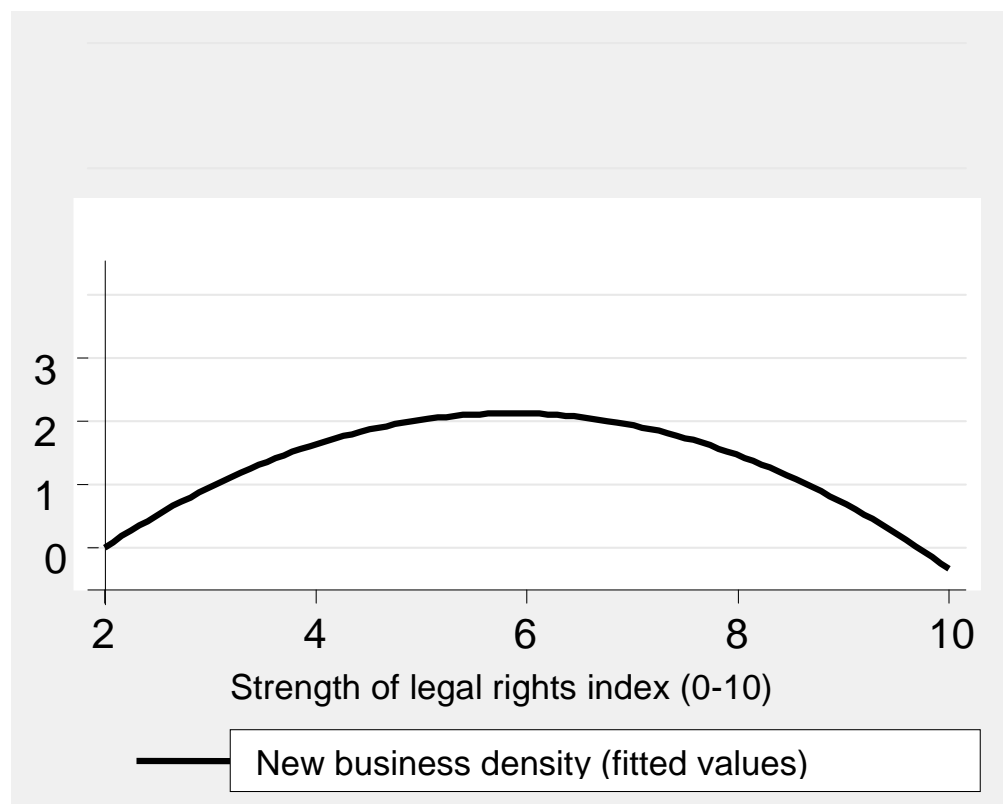

Figure 2. Depth of credit information and entrepreneurship

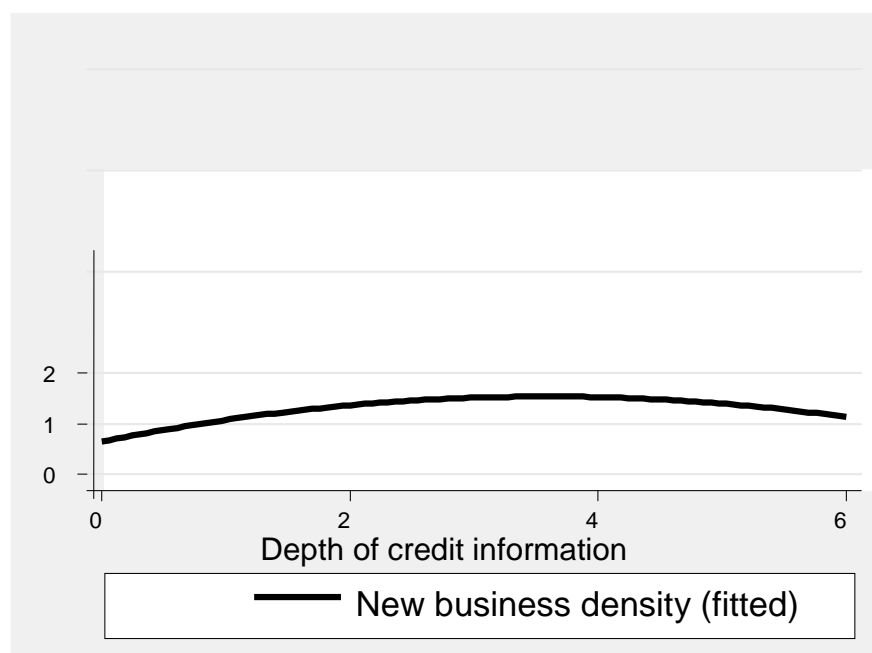


Figure 3. Loans requiring collateral (\%) and new business density

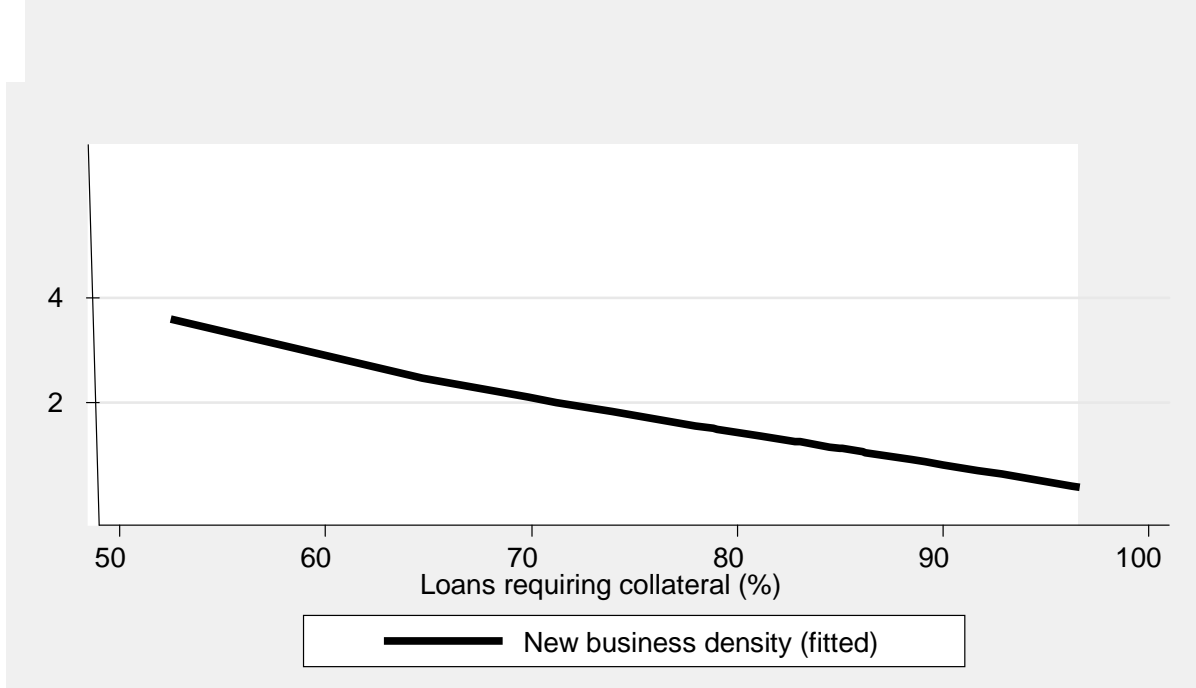

Figure 4. Value of collateral and new business density

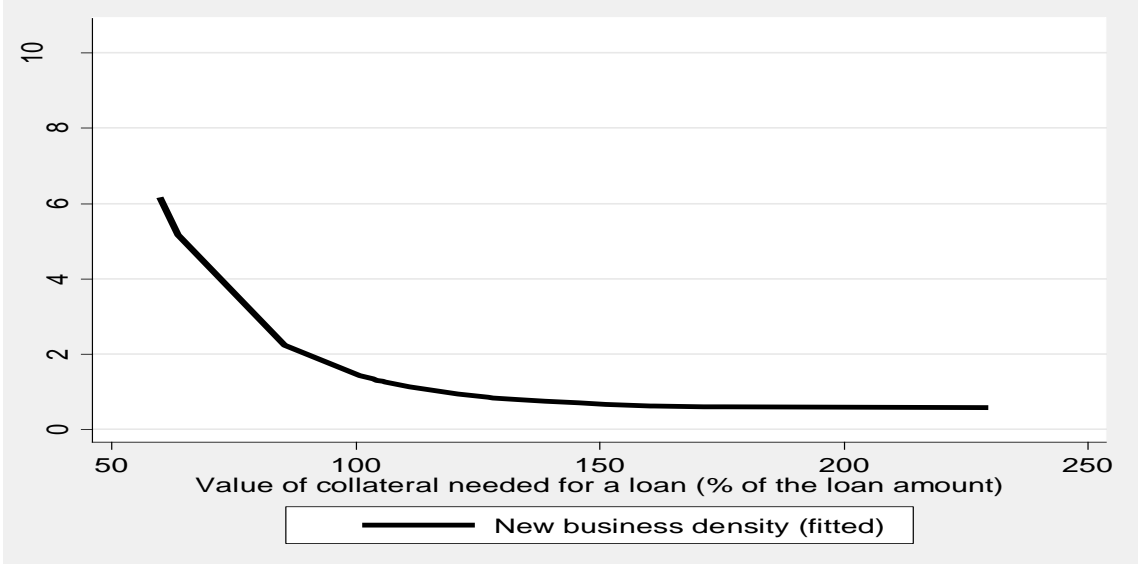

Figure 5. Value of collateral and finance as a major constraint

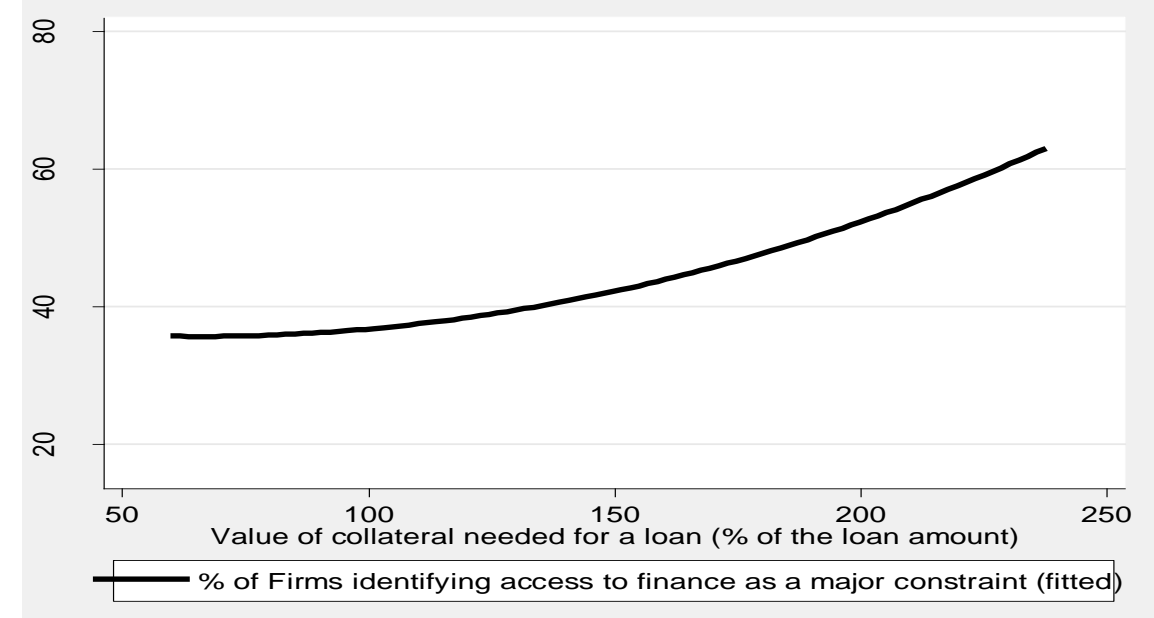


Table1

Correlations

\begin{tabular}{|c|c|c|c|c|c|c|c|c|}
\hline & 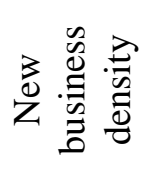 & 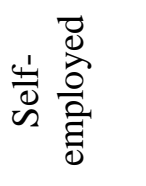 & 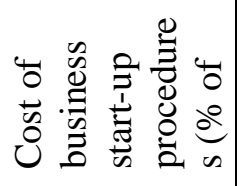 & $\begin{array}{l}\stackrel{0}{\Xi} \\
\stackrel{0}{\Xi} \\
\Xi\end{array}$ & 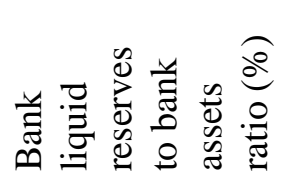 & 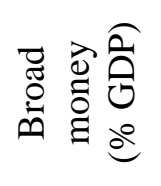 & 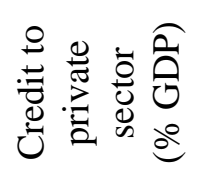 & 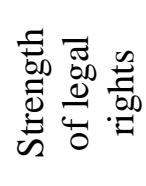 \\
\hline Self-employed & $\begin{array}{l}-0.542 \\
{[0.01]}\end{array}$ & & & & & & & \\
\hline $\begin{array}{l}\text { Cost of business start- } \\
\text { up procedures ( } \% \text { of } \\
\text { GNI per capita) }\end{array}$ & $\begin{array}{l}-0.319 \\
{[0.00]}\end{array}$ & $\begin{array}{l}0.686 \\
{[0.00]}\end{array}$ & & & & & & \\
\hline Income & $\begin{array}{l}0.595 \\
{[0.00]}\end{array}$ & $\begin{array}{l}-0.827 \\
{[0.00]}\end{array}$ & $\begin{array}{l}-0.631 \\
{[0.00]}\end{array}$ & & & & & \\
\hline $\begin{array}{l}\text { Bank liquid reserves to } \\
\text { bank assets ratio }(\%)\end{array}$ & $\begin{array}{l}-0.334 \\
{[0.00]}\end{array}$ & $\begin{array}{l}0.145 \\
{[0.42]}\end{array}$ & $\begin{array}{l}-0.283 \\
{[0.00]}\end{array}$ & $\begin{array}{c}0.313 \\
{[0.00]}\end{array}$ & & & & \\
\hline $\begin{array}{l}\text { Broad money } \\
(\% \text { GDP })\end{array}$ & $\begin{array}{l}0.441 \\
{[0.00]}\end{array}$ & $\begin{array}{c}-0.515 \\
{[0.00]}\end{array}$ & $\begin{array}{l}-0.415 \\
{[0.00]}\end{array}$ & $\begin{array}{l}0.594 \\
{[0.00]}\end{array}$ & $\begin{array}{l}-0.013 \\
{[0.88]}\end{array}$ & & & \\
\hline $\begin{array}{l}\text { Credit to private } \\
\text { sector }(\% \text { GDP) }\end{array}$ & $\begin{array}{l}0.343 \\
{[0.00]}\end{array}$ & $\begin{array}{l}-0.552 \\
{[0.00]}\end{array}$ & $\begin{array}{l}-0.359 \\
{[0.00]}\end{array}$ & $\begin{array}{l}0.554 \\
{[0.00]}\end{array}$ & $\begin{array}{l}-0.338 \\
{[0.00]}\end{array}$ & $\begin{array}{l}0.710 \\
{[0.00]}\end{array}$ & & \\
\hline Strength of legal rights & $\begin{array}{l}0.037 \\
{[0.72]}\end{array}$ & $\begin{array}{l}0.235 \\
{[0.48]}\end{array}$ & $\begin{array}{l}-0.202 \\
{[0.01]}\end{array}$ & $\begin{array}{l}0.057 \\
{[0.59]} \\
\end{array}$ & $\begin{array}{l}-0.172 \\
{[0.15]}\end{array}$ & $\begin{array}{l}0.146 \\
{[0.13]}\end{array}$ & $\begin{array}{l}0.188 \\
{[0.05]}\end{array}$ & \\
\hline $\begin{array}{l}\text { Depth of credit } \\
\text { information }\end{array}$ & $\begin{array}{l}0.117 \\
{[0.27]}\end{array}$ & $\begin{array}{l}-0.437 \\
{[0.17]}\end{array}$ & $\begin{array}{l}-0.346 \\
{[0.00]}\end{array}$ & $\begin{array}{l}0.613 \\
{[0.00]}\end{array}$ & $\begin{array}{l}0.186 \\
{[0.12]}\end{array}$ & $\begin{array}{l}0.411 \\
{[0.00]}\end{array}$ & $\begin{array}{l}0.616 \\
{[0.00]}\end{array}$ & $\begin{array}{l}0.116 \\
{[0.17]}\end{array}$ \\
\hline
\end{tabular}

$\mathrm{P}$-values are in brackets. 
Table 2

Pooled-data estimates

\begin{tabular}{|c|c|c|c|c|c|c|c|}
\hline & \multicolumn{7}{|c|}{ Dependent variable: New business density } \\
\hline & (1) & $(2)$ & (3) & (4) & (5) & (6) & (7) \\
\hline Income $(\log )$ & $\begin{array}{c}0.681^{* * * *} \\
(0.24)\end{array}$ & $\begin{array}{c}1.017 * * * \\
(0.33)\end{array}$ & $\begin{array}{l}1.889 * * * \\
(0.58)\end{array}$ & $\begin{array}{l}2.661 * * * \\
(0.58)\end{array}$ & $\begin{array}{l}2.24 * * * \\
(0.48)\end{array}$ & $\begin{array}{c}1.28 * * * \\
(0.27)\end{array}$ & $\begin{array}{c}1.17 * * * \\
(0.70)\end{array}$ \\
\hline Strength of legal rights & $\begin{array}{c}0.135^{* * * *} \\
(0.05)\end{array}$ & $\begin{array}{c}0.132 * * \\
(0.05)\end{array}$ & $\begin{array}{c}0.271^{* * *} \\
(0.10)\end{array}$ & $\begin{array}{c}0.286^{* * *} \\
(0.12)\end{array}$ & $\begin{array}{c}3.65^{* * * *} \\
(1.06)\end{array}$ & $\begin{array}{l}1.76^{* *} \\
(0.85)\end{array}$ & $\begin{array}{l}1.62 * * \\
(0.77)\end{array}$ \\
\hline $\begin{array}{l}\text { Public credit registry } \\
\text { coverage ( } \% \text { of adults) }\end{array}$ & $\begin{array}{l}0.196^{* * * *} \\
(0.09)\end{array}$ & $\begin{array}{l}0.178^{*} \\
(0.09)\end{array}$ & $\begin{array}{l}0.153 \\
(0.13)\end{array}$ & & & & \\
\hline $\begin{array}{l}\text { Depth of credit } \\
\text { information }\end{array}$ & & $\begin{array}{c}-0.414 * * \\
(0.18) \\
\end{array}$ & $\begin{array}{c}-0.680 * * * \\
(0.24)\end{array}$ & $\begin{array}{c}-0.495 * * * \\
(0.17)\end{array}$ & $\begin{array}{l}1.441 \\
(1.01) \\
\end{array}$ & $\begin{array}{l}0.463 \\
(0.73) \\
\end{array}$ & $\begin{array}{l}0.623 \\
(0.74) \\
\end{array}$ \\
\hline $\begin{array}{l}\text { Bank liquid reserves to } \\
\text { bank assets ratio (\%) }\end{array}$ & & & $\begin{array}{c}-2.449^{*} \\
(1.28)\end{array}$ & $\begin{array}{c}-4.750^{* * * *} \\
(1.39)\end{array}$ & $\begin{array}{c}-3.891 * * * \\
(0.96)\end{array}$ & & \\
\hline $\begin{array}{l}\text { Strength of legal } \\
\text { rights_squared }\end{array}$ & & & & & $\begin{array}{c}-0.264 * * * \\
(0.07)\end{array}$ & $\begin{array}{c}-0.133 * * \\
(0.06)\end{array}$ & $\begin{array}{c}-0.123^{* *} \\
(0.06)\end{array}$ \\
\hline $\begin{array}{l}\text { Depth of credit } \\
\text { information_squared }\end{array}$ & & & & & $\begin{array}{l}-0.354 \\
(0.21) \\
\end{array}$ & $\begin{array}{l}-0.174 \\
(0.135) \\
\end{array}$ & $\begin{array}{l}-0.271 \\
(0.162) \\
\end{array}$ \\
\hline $\begin{array}{l}\text { Broad money } \\
\text { (\% of GDP) }\end{array}$ & & & & & & $\begin{array}{l}-0.010 \\
(0.11)\end{array}$ & \\
\hline $\begin{array}{l}\text { Credit to private sector (\% } \\
\text { of GDP) }\end{array}$ & & & & & & & $\begin{array}{c}0.021 \\
(0.013)\end{array}$ \\
\hline Observations & 74 & 74 & 42 & 42 & 42 & 73 & 73 \\
\hline Fstat & 8.15 & 9.69 & 3.85 & 7.88 & 6.27 & 6.04 & 5.54 \\
\hline R-squared & 0.50 & 0.57 & 0.65 & 0.61 & 0.72 & 0.50 & 0.53 \\
\hline
\end{tabular}

Robust standard errors are in parentheses.

$*$ indicates significance at $0.10 * *$ indicates significance at 0.05 and $* * *$ indicates significance at 0.01 . 
Table 3

Random-effects GLS estimates

\begin{tabular}{|c|c|c|c|c|}
\hline & \multicolumn{4}{|c|}{ Dependent variable: New business density } \\
\hline & (1) & $(2)$ & $(3)$ & (4) \\
\hline Income (log) & $\begin{array}{l}2.153 * * * \\
(0.64)\end{array}$ & $\begin{array}{l}0.978 * * \\
(0.41)\end{array}$ & $\begin{array}{l}2.388 * * * \\
(0.74)\end{array}$ & $\begin{array}{l}1.003 * * \\
(0.43)\end{array}$ \\
\hline Strength of legal rights & $\begin{array}{l}3.82 * * * \\
(1.44)\end{array}$ & $\begin{array}{l}1.78 * \\
(0.95)\end{array}$ & $\begin{array}{l}3.89 * * * \\
(1.5)\end{array}$ & $\begin{array}{l}1.78 * \\
(0.96)\end{array}$ \\
\hline Depth of credit information & $\begin{array}{l}0.993 * * * \\
(0.19)\end{array}$ & $\begin{array}{l}0.495 * * * \\
(0.15)\end{array}$ & $\begin{array}{l}0.959 * * * \\
(0.20)\end{array}$ & $\begin{array}{l}0.493 * * * \\
(0.16)\end{array}$ \\
\hline $\begin{array}{l}\text { Bank liquid reserves to bank assets } \\
\text { ratio }(\%)\end{array}$ & $\begin{array}{c}-1.162 * * * \\
(0.58)\end{array}$ & & $\begin{array}{c}-1.07^{*} \\
(0.59)\end{array}$ & \\
\hline Strength of legal rights_squared & $\begin{array}{c}-0.278 * * \\
(0.11)\end{array}$ & $\begin{array}{c}-0.148 * \\
(0.08)\end{array}$ & $\begin{array}{c}-0.280^{* *} \\
(0.12)\end{array}$ & $\begin{array}{l}-0.148 * \\
(0.08)\end{array}$ \\
\hline Depth of credit information_squared & $\begin{array}{c}-0.186 * * * \\
(0.04)\end{array}$ & $\begin{array}{c}-0.089 * * \\
(0.04)\end{array}$ & $\begin{array}{c}-0.175 * * * \\
(0.04)\end{array}$ & $\begin{array}{c}-0.089 * * \\
(0.03)\end{array}$ \\
\hline Credit to private sector ( $\%$ of GDP) & & $\begin{array}{l}0.009 \\
(0.01)\end{array}$ & & $\begin{array}{c}0.009 \\
(0.009)\end{array}$ \\
\hline $\begin{array}{l}\text { Cost of business start-up procedures } \\
\text { (\% of GNI per capita) }\end{array}$ & & & $\begin{array}{c}0.003 \\
(0.004)\end{array}$ & $\begin{array}{l}0.0003 \\
(0.001)\end{array}$ \\
\hline Observations & 42 & 73 & 42 & 73 \\
\hline $\begin{array}{l}\text { Wald chi } 2 \\
\text { Prob > chi } 2\end{array}$ & $\begin{array}{l}53.58 \\
(0.00)\end{array}$ & $\begin{array}{l}30.59 \\
(0.00)\end{array}$ & $\begin{array}{l}53.02 \\
(0.00)\end{array}$ & $\begin{array}{l}30.20 \\
(0.00)\end{array}$ \\
\hline $\begin{array}{c}\text { R-squared } \\
\text { Within } \\
\text { Between } \\
\text { Overall }\end{array}$ & $\begin{array}{l}0.60 \\
0.63 \\
0.65\end{array}$ & $\begin{array}{l}0.26 \\
0.44 \\
0.43\end{array}$ & $\begin{array}{l}0.60 \\
0.65 \\
0.67\end{array}$ & $\begin{array}{l}0.26 \\
0.44 \\
0.43\end{array}$ \\
\hline
\end{tabular}

Robust standard errors are in parentheses.

$*$ indicates significance at $0.10 * *$ indicates significance at 0.05 and $* * *$ indicates significance at 0.01 . 


\section{Appendix A}

Figure A1. Access to finance and collateralization

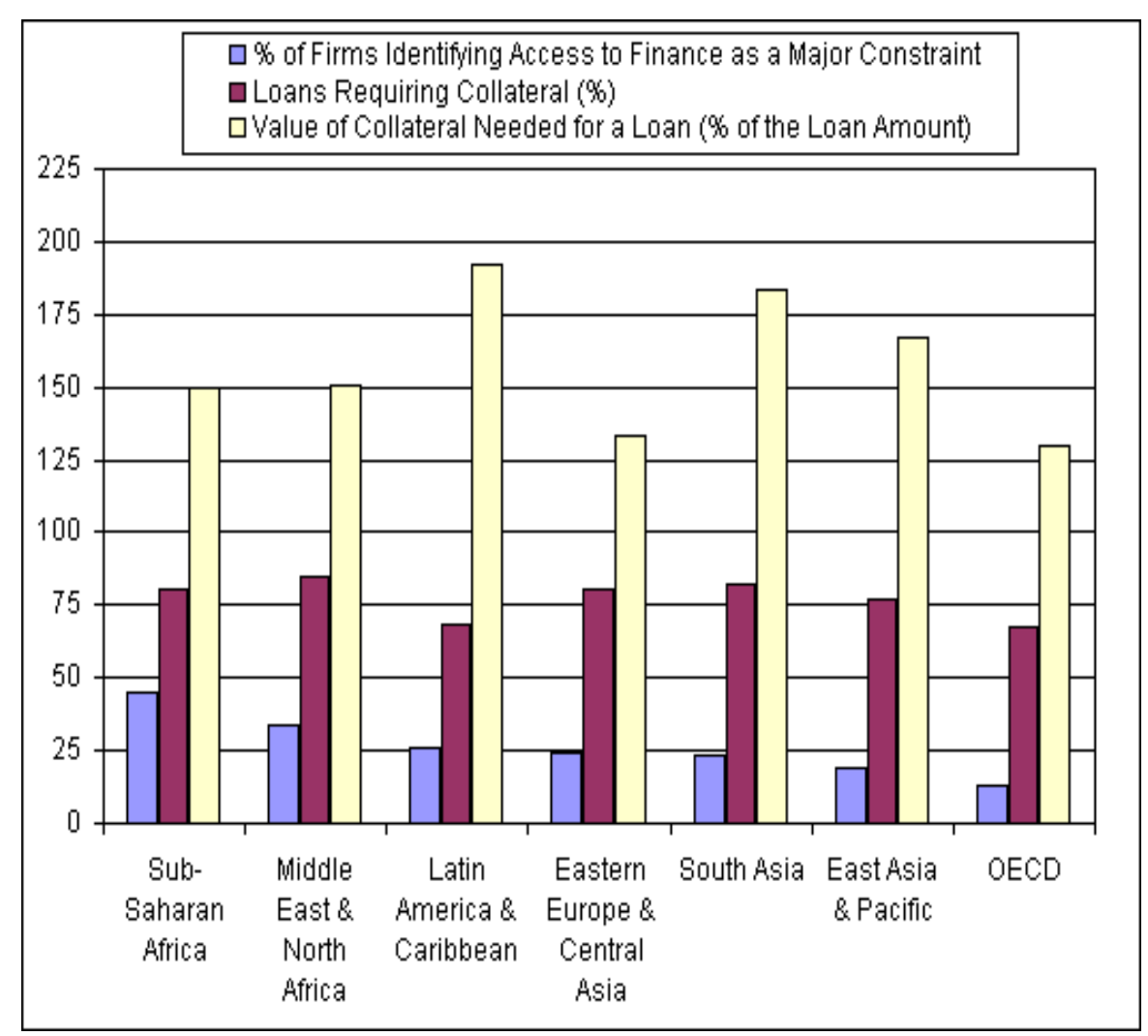

Figure A2. Extent of formal registration

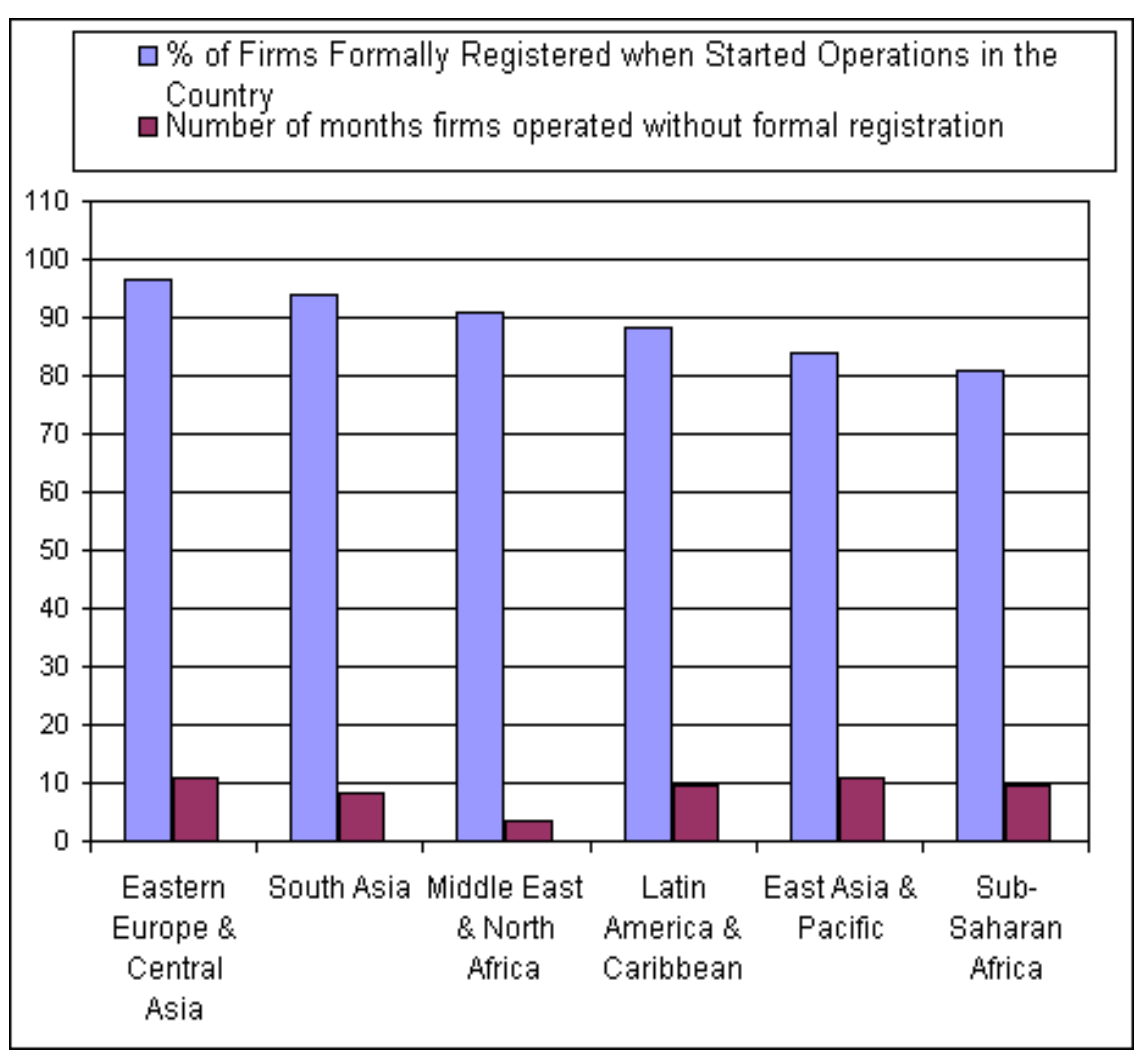

Source of data: Enterprise survey, World Bank's Enterprise database (based on various years during 2002-2010) 
Figure A3. \% of Firms Formally Registered when Started Operations in the Country

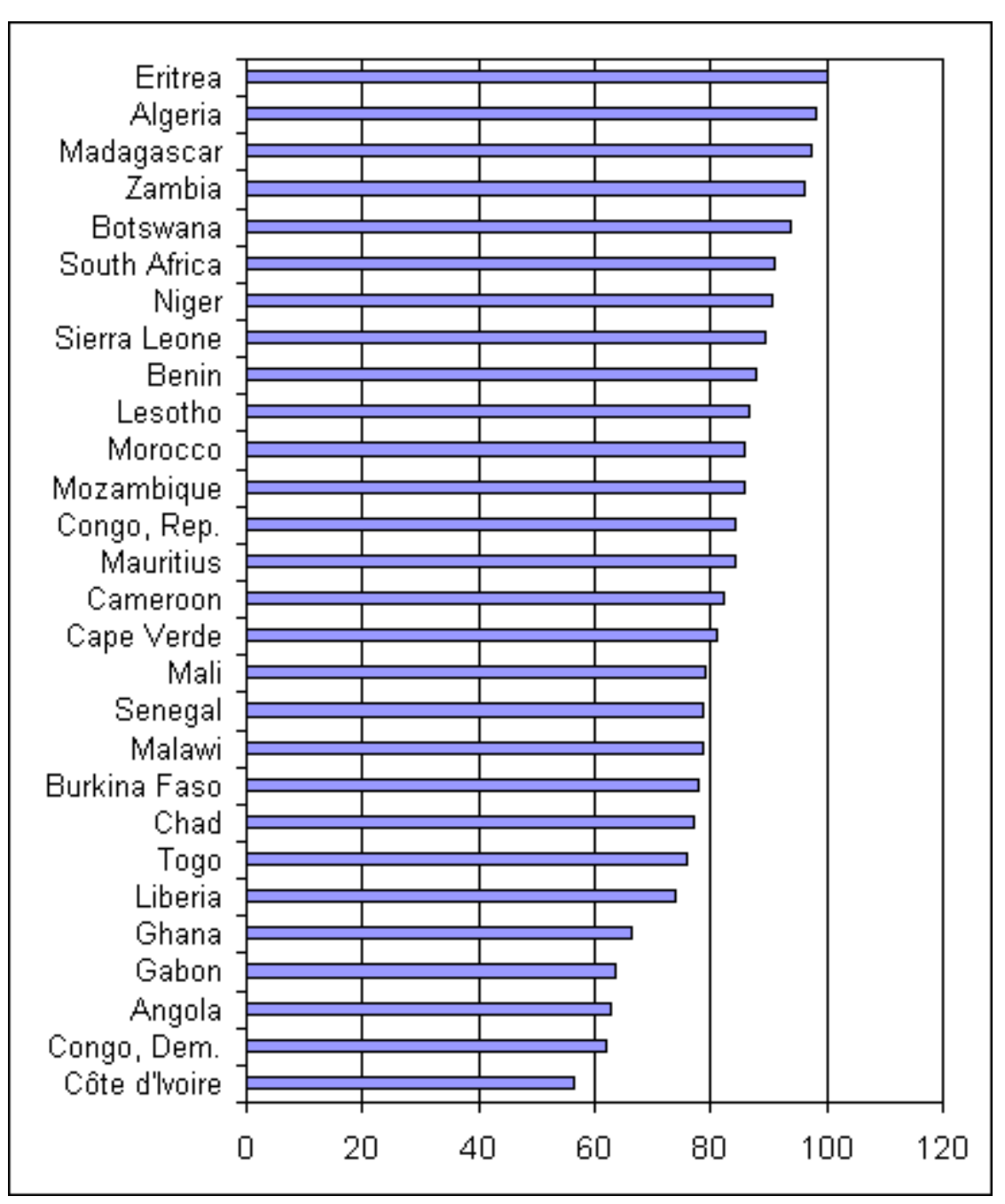

Figure A4. Number of years firms operated without formal registration

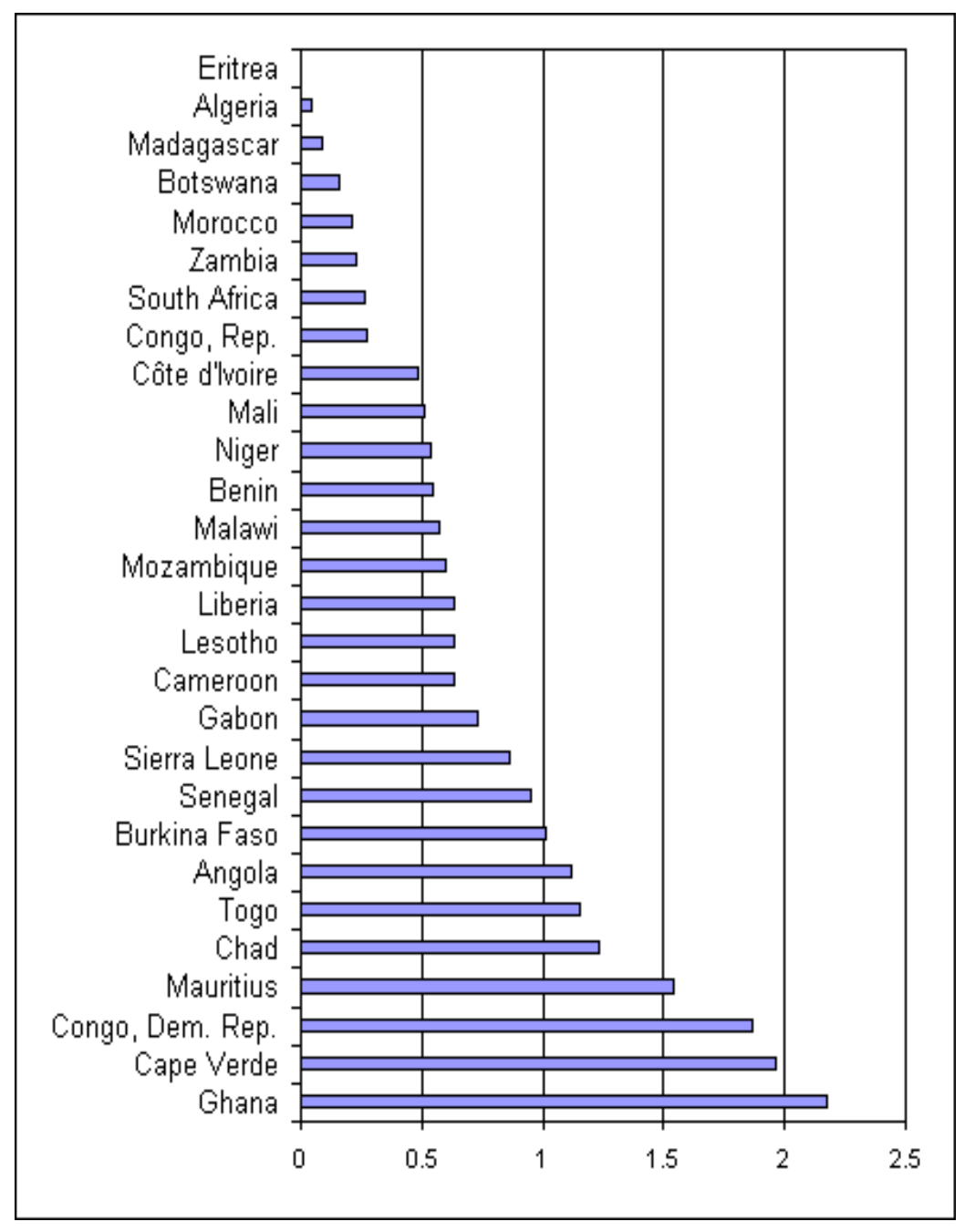

Source of data: World Bank's Enterprise database (based on various years during 2007-2010) 
Figure A5: Percentage of firms identifying access to finance as a major constraint

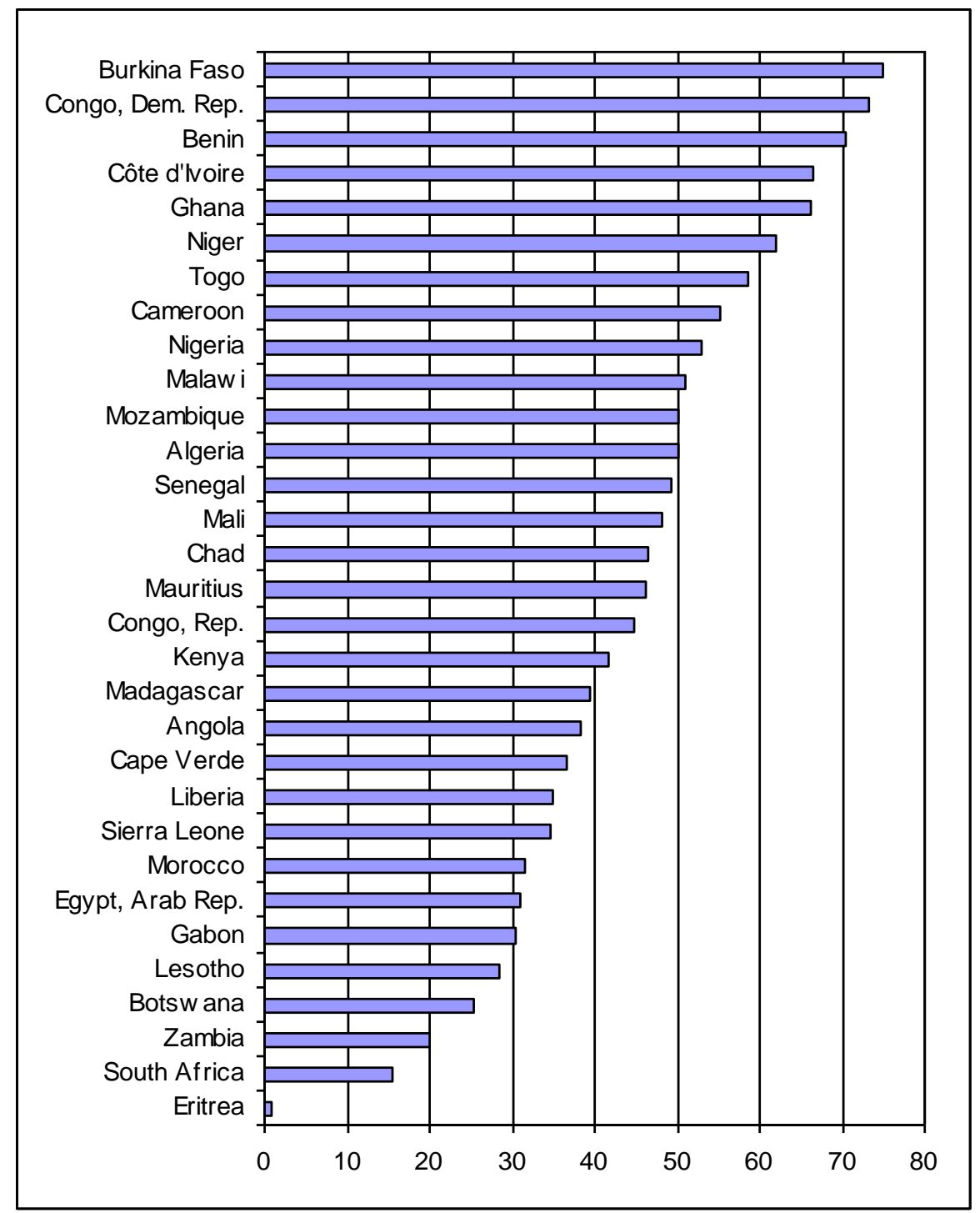

Source of data: World Bank's Enterprise database (based on various years during 2007-2010) 
Figure A6. Percentage of firms using banks to finance investments and firms with lines of credit or loans from financial institutions

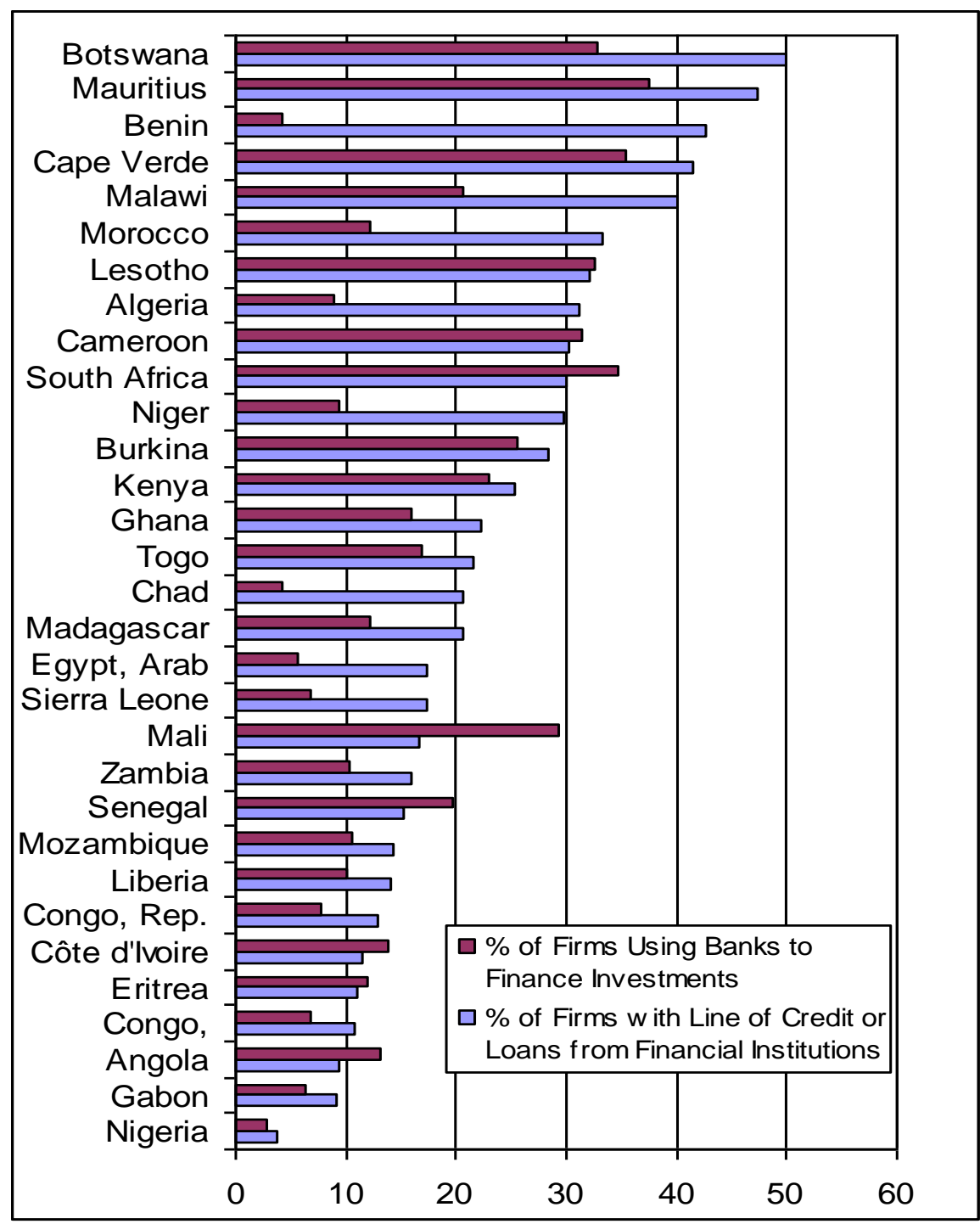

Source of data: World Bank's Enterprise database (based on various years during 2007-2010) 
Figure A7. Loans requiring collateral and value of collateral

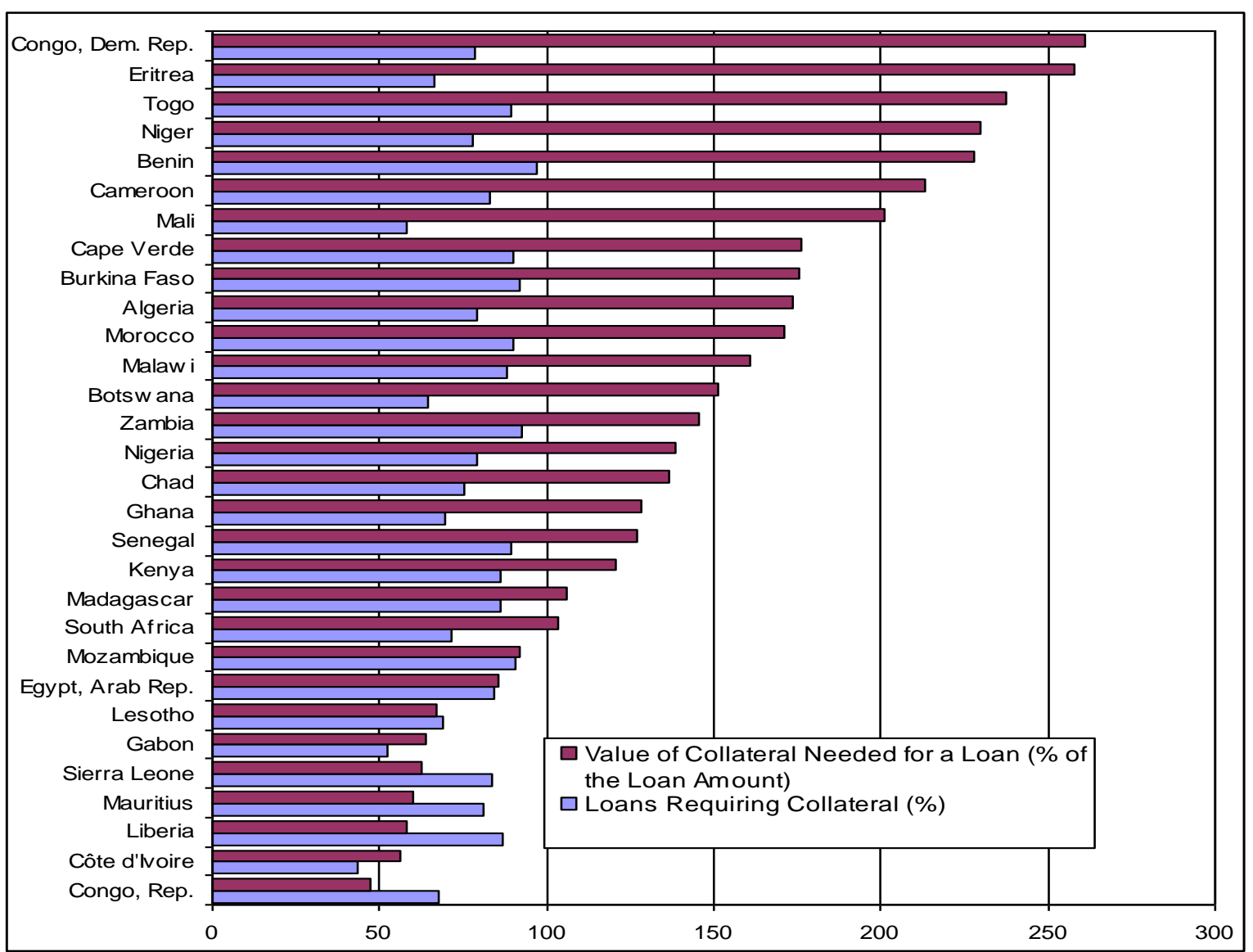

Source of data: World Bank's Enterprise database (based on various years during 2007-2010)

\section{Appendix B}

Table B1

List of countries

\begin{tabular}{|l|l|l|}
\hline Algeria & Madagascar* & Senegal* \\
\hline Burkina Faso* & Malawi* & South Africa \\
\hline Egypt & Mauritius & Togo \\
\hline Ethiopia* & Morocco & Tunisia \\
\hline Gabon* & Niger* & Uganda \\
\hline Ghana & Nigeria* & Zambia \\
\hline Kenya & Rwanda* & \\
\hline
\end{tabular}

* Not included in the larger sample (20 countries). 